University of Nebraska - Lincoln

DigitalCommons@University of Nebraska - Lincoln

Textile Society of America Symposium

Proceedings

2020

Aso Òkè Weaving Techniques and Perception in Iseyin, Oyo State,

Nigeria

Idowu Jamiu Diyaolu

Halima Ronke Omotosho

Follow this and additional works at: https://digitalcommons.unl.edu/tsaconf

Part of the Art and Materials Conservation Commons, Art Practice Commons, Fashion Design Commons, Fiber, Textile, and Weaving Arts Commons, Fine Arts Commons, and the Museum Studies Commons

This Article is brought to you for free and open access by the Textile Society of America at DigitalCommons@University of Nebraska - Lincoln. It has been accepted for inclusion in Textile Society of America Symposium Proceedings by an authorized administrator of DigitalCommons@University of Nebraska - Lincoln. 


\title{
Aso Òkè Weaving Techniques and Perception in Iseyin, Oyo State, Nigeria
}

\author{
Idowu Jamiu Diyaolu and Halima Ronke Omotosho \\ diyaolv@oavife.edu.ng
}

The weaving of Aso Òkè is an old age craft among Nigerians as different ethnic groups have local fabrics cherished among the members. More importantly, Aso Òkè is very significant to the Yoruba group of Southwestern Nigeria. This is evidenced in its usage in socio-cultural events. ${ }^{1}$ Its popularity and usage have gone beyond the Yoruba as it is adopted by other ethnic groups within and outside the country. It is a form of identity that links generations of the Yoruba race. Besides its cultural imports, the weaving of Aso Okè employs both men and women in Yoruba communities and is noteworthy making it a sustainable and veritable enterprise for national development.

The term Aso Òkè (also known as aso ofi) generally refers to products from the horizontal loom and cloths made of it. ${ }^{2}$ The etymology of the name Aso Òkè dated back to the late 19th century when people from the Iseyin area (Oke Ogun) were referred to by Lagos merchants as 'Ara Oke' (people from Oke Ogun or Yoruba hinterland). When the cloth made in Iseyin is taken to Lagos for sale, people in Lagos would call the clothe Aso awon Ara Oke (clothe of the people from the hinterland). It is called Aso of $i$ because of the process through which it is made, particularly the loom. Aso is the Yoruba name for 'clothe' while 'ofi' is the loom with which this type of clothing is woven. ${ }^{3}$ The loom used in Nigeria local weaving could be a horizontal narrowband or vertical loom. Cotton, the primary raw material used in the production of Aso Òkè is either locally sourced or imported, although current trends in production adopt the use of synthetic yarns for weaving.

Aso Òkè is used as aso-ebi (customized uniform or commemorative dress). Aso-ebi connotes the wearing of a chosen or commissioned cloth as a uniform dress to commemorate or celebrate an event. Aso-ebi is seen as a strong expression of communal ties, solidarity and love. ${ }^{4}$ Aso Òkè still finds usage in religious activities in egungun costume.

Three major types of Aso-Oke: etu, alaari and sanyan with many variations, have been identified. ${ }^{5}$ However, modern names have been given to the designs such as baby computer, carpet, wire-to-wire among others. While etu is dark blue, sanyan has carton brown colour while alaari is crimson.

\footnotetext{
${ }^{1}$ I. J. Diyaolu, "Role of dress in Socio-cultural events among the Ijebu-Yoruba, Ogun State, Nigeria," Journal of Home Economics Research 13, (2010), 35-41.

${ }^{2}$ B. A. Ademuleya, "Ondo in the history of Aso-oke weaving in southwestern Nigeria," Mediterranean Journal of Black and African Arts and Civilization. 5 no. 11 (2014), 129-144.

${ }^{3}$ A. O. Olutayo and O. Akanle, "Aso-oke (Yoruba's hand-woven textiles) usage among the youths in Lagos, Southwestern Nigeria," International Journal of Sociology and Anthropology 1 no. 3 (2009), 062-069.

${ }^{4}$ P. S. O. Aremu, "Yoruba Traditional Weaving: Kijipa Motifs, Colour Symbols," Nigeria Magazine, no. 4 (1982).

${ }^{5}$ Makinde D. Olajide, Ajiboye Olusegun Jide and Ajayi Babatunde Joseph, "Aso-Oke Production and Use among the Yoruba of Southwestern Nigeria” The Journal of Pan African Studies, no.3, 3 (2009) 55-72.
} 

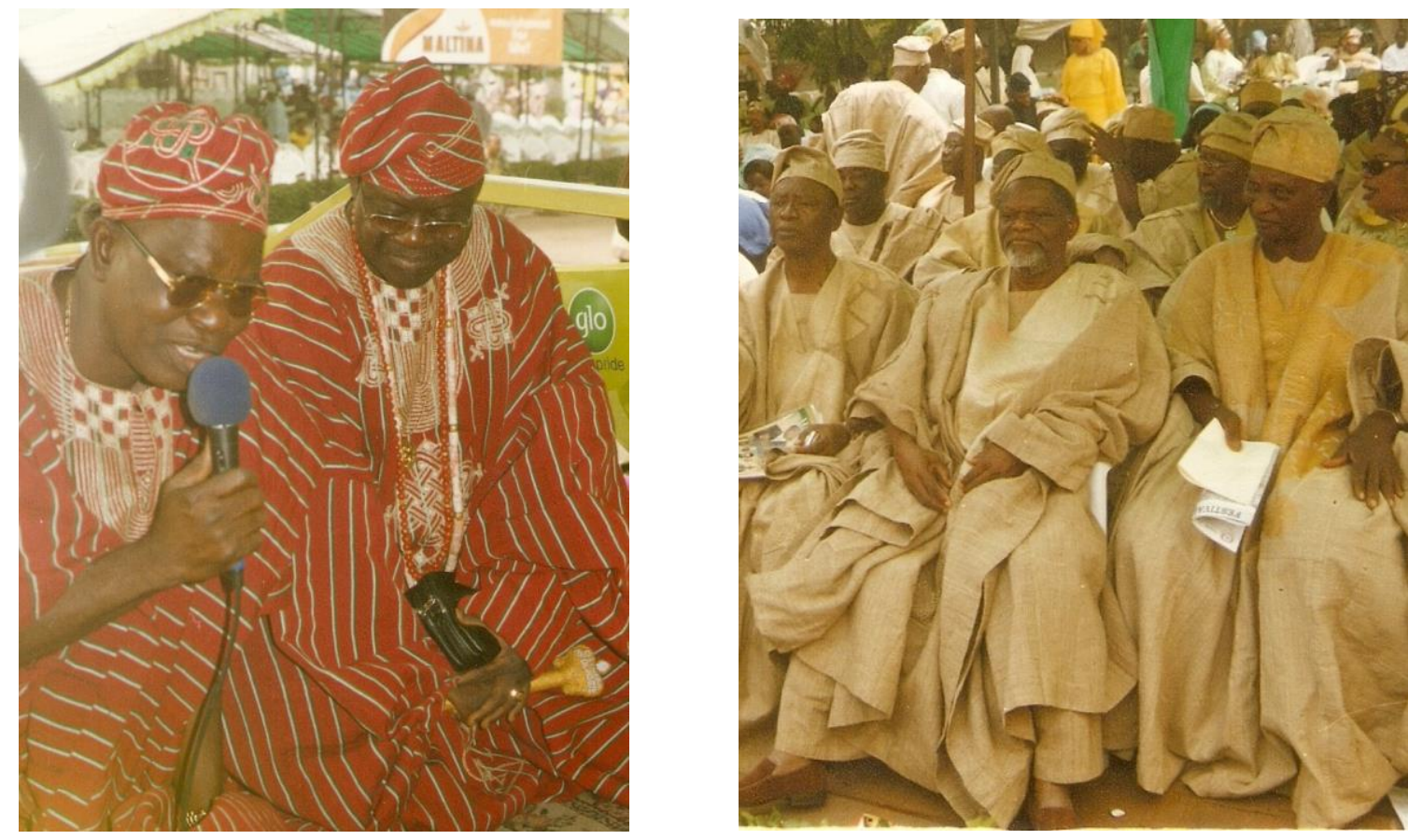

Aso Òkè used for a socio-cultural event in Yoruba land (paying homage to the king) left is alaari right is sanyan, collections of Diyaolu I. J. ${ }^{6}$

The weaving of Aso Òkè among the Yoruba Weather condition such as rain is one of the major problems facing horizontal narrow band loom, weavers. Since the processes involved require space (for warping) the weavers are always upsets by running up and down to pack their warps when the rain starts. Preference for imported fabrics over locally woven ones is militating against production. Besides, people employed in offices, factories, hospitals and schools etc. often find it more convenient to wear corporate dresses. Demand for traditional woven fabrics has decreased due to competition from the elaborately embroidered fabric known as lace. Low profit generated due to a small quantity in the production and demand led to the backwardness of Aso Òkè. The exorbitant price of raw materials, limitation in traditional and contemporary uses and modernization were other factors hindering Aso Òkè production. ${ }^{7}$

Thus, over the years weaving activities and patronage of Aso Òkè have reduced due to high acceptance of foreign fabrics to local fabrics. The influx of western garment and acculturation could have necessitated these developments. Their use is limited to chieftaincy, festivals, engagement and other important events. It is therefore important to survey the current factors associated with weaving among the Yoruba in Nigeria and also examine people's perception of woven fabrics.

The study aimed examined the production process of Aso Òkè in Iseyin, Oyo State, identified the factors influencing the production of Aso Òkè and assessed the perception of users on Aso Òkè.

\footnotetext{
${ }^{6}$ I. J. Diyaolu, "Significance and Form of the Dress of Age-Grade in Ojude-Oba Festival of Ijebu-Ode, Ogun State, Nigeria," MSc. Dissertation, Home Science and Management Department, University of Agriculture Abeokuta, (2009).

${ }^{7}$ B. Ojo, An appraisal of Weaving Cottage Industry in South-Western Nigeria, in Potentials of Visual Arts and Creativity, CCAF Publication, (2006).
} 


\section{Methodology}

The study was carried out in Iseyin, Oyo state. The primary industry of the area is cottonbased textiles, and it is reputed as the home of Aso Òkè. Iseyin is the fourth largest city in Oyo state, after Ibadan, Ogbomosho and Oyo. Iseyin is also known as the home of Aso Òkè. It is centrally located and accessible via road network from Ibadan, Oyo, Abeokuta and Ogbomosho. Iseyin is a town of weavers as weaving has been produced since the early seventeenth century. ${ }^{8}$

It is a traditional centre for cotton spinning and weaving and is best known for dyeing (usually locally grown indigo as well as imported dyes) of heavy imported cloth. These make Iseyin suitable for the study.

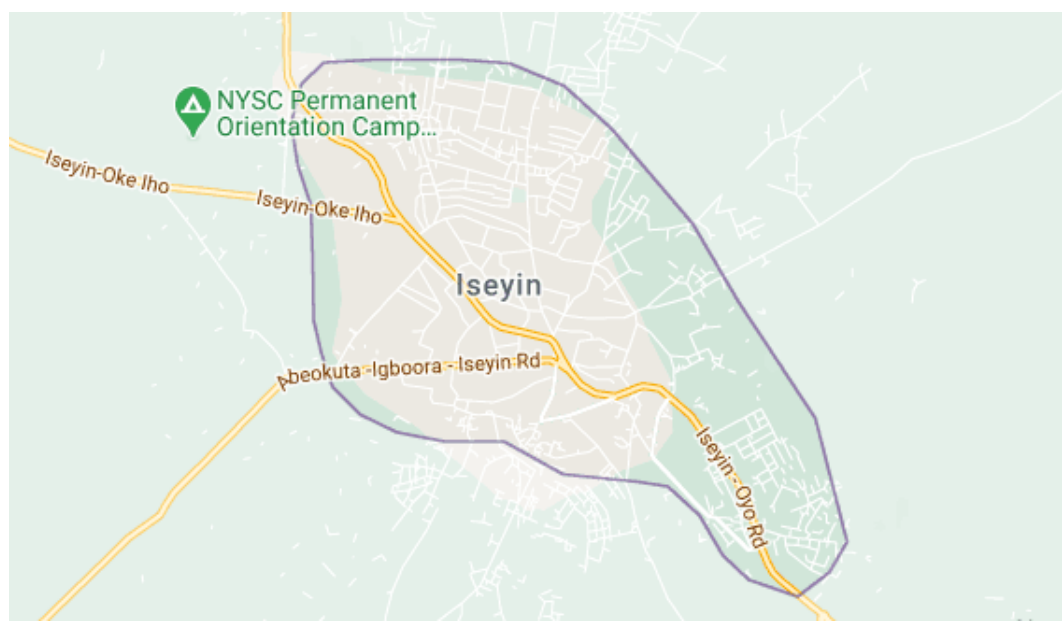

Geo map of Iseyin, located on coordinate $7^{\circ} 58^{\prime} \mathrm{N} 3^{\circ} 36^{\prime} \mathrm{E}$, an online collection ${ }^{9}$

A descriptive survey design was used for the study. The population of the study consisted of weavers and consumers of Aso Òkè in the study area. Two groups of respondents were used for the study. The first group consists of the weavers involved in the production of Aso Òkè while the second group consisted of the users who buy and use Aso Ôkè for events. The users were selected to reveal their perception of the use of Aso Òkè. A clustered sampling technique was used to select 20 weavers within Iseyin while purposive sampling was used to select 80 users within the study area.

A structured questionnaire and interview schedule were used to gather the information from the respondents. Data were analyzed using descriptive statistics such as percentage and frequency.

\section{Findings}

\section{General Information of the Weavers}

About 60 percent of the firms have been in existence 20 years ago, 30 percent between 21 and 40 years and 10 percent between 41 and 60 years. This asserted the fact that weaving tradition in the area is age-long. A majority ( 80 percent) of the weavers had less than 21 employees, 15 percent had between 21 and 40 and 5 percent had between 41 and 60 employees. All the respondents had horizontal looms. Horizontal loom existed in the Yoruba

\footnotetext{
${ }^{8}$ C. B. Dowell, "Iseyin: The Town of Weavers" Nigeria Magazine, (Lagos, 1955) 118-145. ${ }^{9} \mathrm{https} / / / \mathrm{www}$. google.com/search?q=iseyin+gps+location\&oq=iseyin+gps+location+\&aqs=chrome..69i57j0i333. 19736j0j9\&sourceid=chrome \&ie=UTF-8.
} 
traditional weaving scene before the colonial contacts. ${ }^{10}$ About 75 percent of the respondents used cotton as their major yarn. Just 10 percent of the respondents operated on a micro-scale, 30 percent on small scale, 40 percent on a medium scale and 20 percent on large scale. Most ( 80 percent) of the respondents targeted the local market. A majority ( 75 percent) of the respondents used their phone to communicate with customers, 15 percent used e-mail and 10 percent used Short Message Services. About 40 percent of the respondents spent between $\$ 10,000$ and $\$ 20,000$ on the production process, 10 percent spent between $\$ 21,000$ and $\$ 30,000$ and 50 percent spent from $\$ 31,000$ and above.

\section{Production Processes}

The pre-weaving process of Aso Òkè begins with the planting of cotton, harvesting, ginning, combing and spinning process. ${ }^{11}$ All the activities were carried out manually. The various components of the loom used in weaving included the shuttle, warp thread, weft thread, heddle, shaft, beater, roller and drag stone. The production process begins with the preparation of yarn for weaving, followed by shedding, picking, battening, letting off, and sorting. All the weavers engage in these processes.

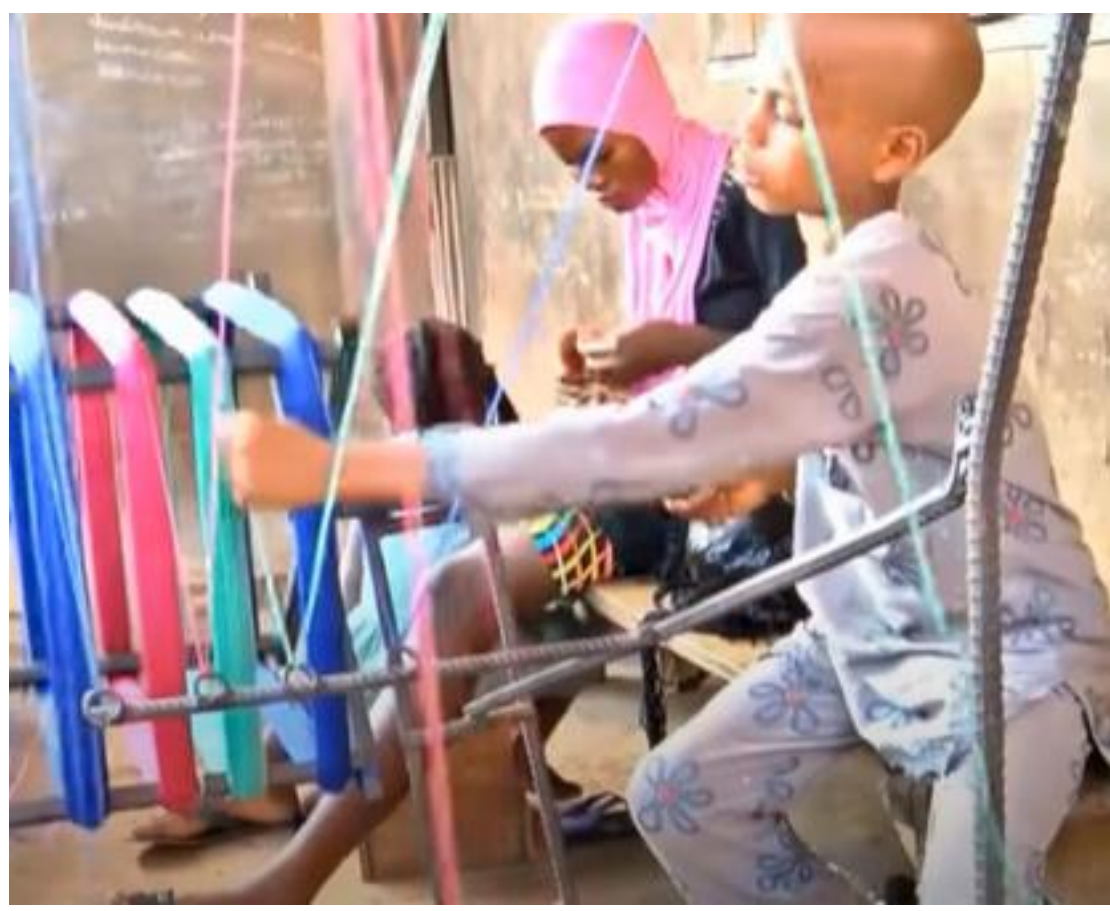

Preparing the yarn for weaving.

Collection from https://www.youtube.com/watch? $v=r p T H d y 8 Y z 9 M$

The design on the aso-oke is predetermined before weaving. The weaver selects the shades of colour to enhance beauty and aesthetics. Shedding is the raising of part of the warp yarn to form a shed (the vertical space between the raised and unraised warp yarns), through which the weft or filling yarn, carried by shuttle, can be inserted. The insertion of the filling yarn through the shuttle is referred to as picking. Battening involves using the reed to press (or

\footnotetext{
${ }^{10}$ V. Lamb \& A. Lamb, West African strips weaving. (Halifax: Halifax museum, 1976).

${ }^{11}$ A. O. Olutayo, A. Olayinka and O. A. Fadina, "Aso-oke (Hand-Woven Textiles) of Southwestern Nigeria a Compact Examination of a Resilient Artifact," American Journal of Sociological Research 1 no. 1 (2011), 9-17.
} 
batten) each filling yarn against the fell. The production processes are being sustained through frequent product modifications. The fabric appears to be both a style and a fashion. ${ }^{12}$

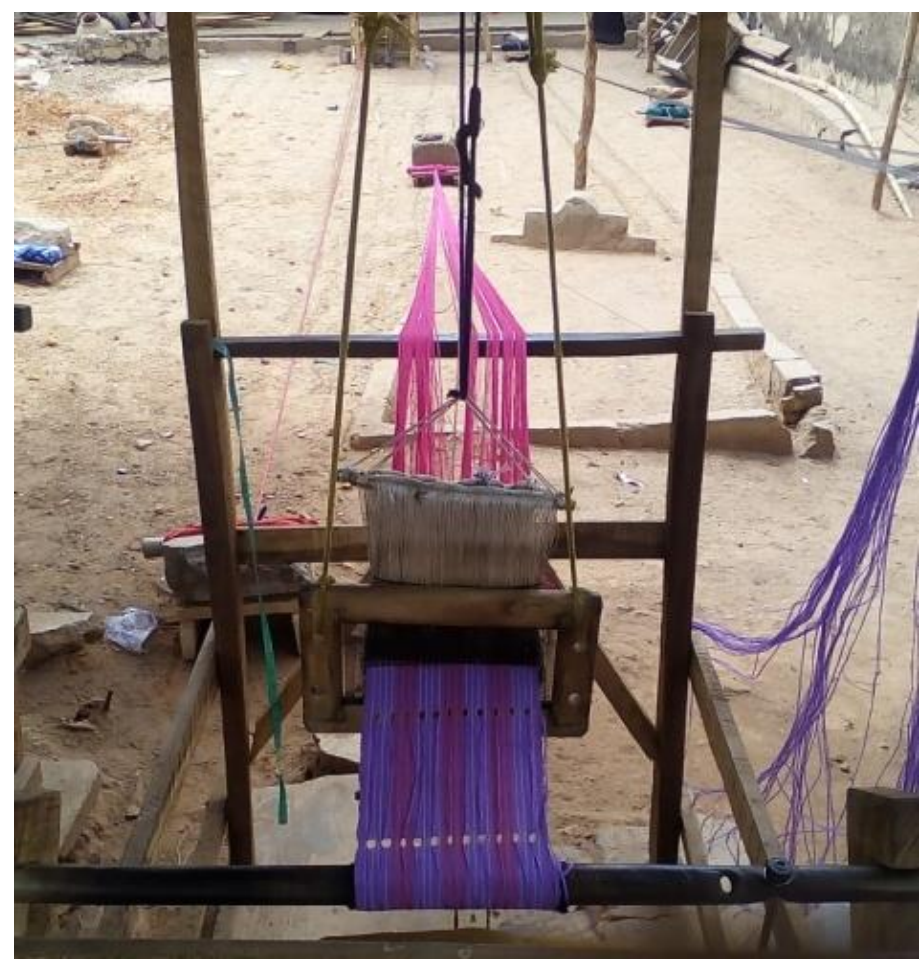

Narrowband loom showing the beater, warp thread and the frame, collection of Author

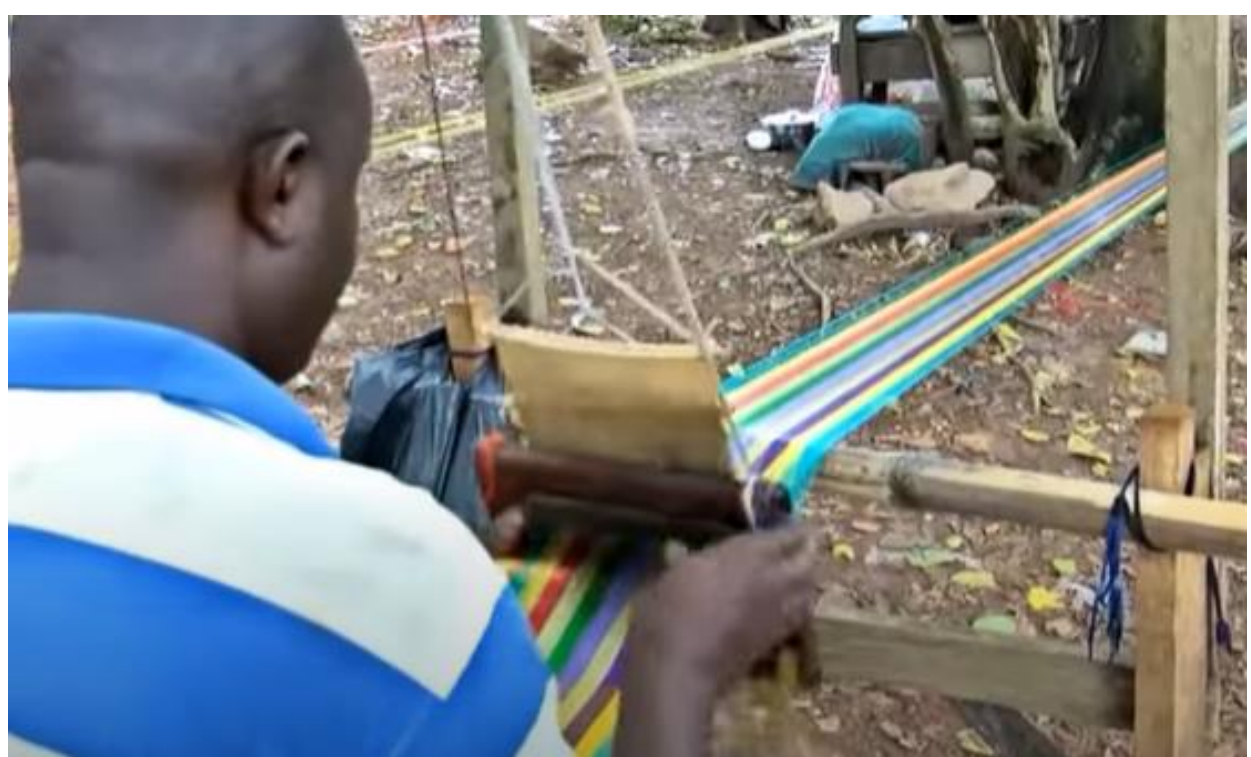

The weaving process involving shedding, picking and battening Collection from https://www.youtube.com/watch? $v=r p T H d y 8 Y z 9 M$

${ }^{12}$ A. B. Agbadudu and F. O. Ogunrin, "Aso- oke: a Nigerian classic style and fashion fabric," Journal of Fashion Marketing and Management, no. 1, 10 (2006) 97-113. 
Table 1: Factors Influencing Weaving

\begin{tabular}{llll}
\hline Factors & Always & Sometimes & Never \\
\hline Availability of capital & $7(35 \%)$ & $13(65 \%)$ & $0(0 \%)$ \\
High cost of raw materials & $7(35 \%)$ & $10(50 \%)$ & $3(15 \%)$ \\
Location & $6(30 \%)$ & $9(45 \%)$ & $5(25 \%)$ \\
Low patronage & $3(15 \%)$ & $14(70 \%)$ & $3(15 \%)$ \\
Low profit & $3(15 \%)$ & $15(75 \%)$ & $2(10 \%)$ \\
High cost of labour & $8(40 \%)$ & $9(45 \%)$ & $3(15 \%)$ \\
Access to loan & $3(15 \%)$ & $10(50 \%)$ & $7(35 \%)$ \\
Weather condition & $3(15 \%)$ & $17(85 \%)$ & $0(0 \%)$ \\
Cost of maintaining loom & $4(20 \%)$ & $11(55 \%)$ & $5(25 \%)$ \\
Government policies & $5(25 \%)$ & $6(30 \%)$ & $9(45 \%)$ \\
Influx of western garment & $5(25 \%)$ & $11(55 \%)$ & $4(20 \%)$ \\
Occasion people want to do & $2(10 \%)$ & $17(85 \%)$ & $1(5 \%)$ \\
\hline
\end{tabular}

\section{Factors Influencing Weaving}

The majority of the weavers agreed that weaving is sometimes influenced by the availability of capital (65 percent), low patronage (70 percent) and the cost of maintaining a loom (55 percent). Others include low profit ( 75 percent), weather condition ( 85 percent), the influx of western garment (55 percent) and occasion people want to do (85 percent). Availability of capital to purchase raw materials in bulk often affects the weavers. When the level of patronage is low, there will be less motivation to produce in large quantities. Besides, weaving on a loom is equally demanding as it involves exertion of strength and energy among the weavers. Today, weavers are using more colourfast yarns to produce a more durable fabric. Lightweight and shrink resistance could enhance a better product. 
Table 2: Users Perception of the Use of Aso Òkè

\begin{tabular}{|c|c|c|c|c|}
\hline Statements & $\begin{array}{l}\text { Strongly } \\
\text { agree }\end{array}$ & Agree & Disagree & $\begin{array}{l}\text { Strongly } \\
\text { disagree }\end{array}$ \\
\hline Aso Òkè is durable and lasts long & $36(45.0 \%)$ & $44(55.0 \%)$ & $0(0.0 \%)$ & $0(0.0 \%)$ \\
\hline I can wear them for any occasion & $29(36.3 \%)$ & $44(55.0 \%)$ & $6(7.5 \%)$ & $1(1.3 \%)$ \\
\hline They are colour fast & $24(30.0 \%)$ & $50(62.5 \%)$ & $4(5.0 \%)$ & $2(2.5 \%)$ \\
\hline $\begin{array}{l}\text { I feel comfortable when I wear Aso } \\
\text { Òkè }\end{array}$ & $36(45.0 \%)$ & $33(41.3 \%)$ & $10(12.5 \%)$ & $1(1.3 \%)$ \\
\hline They are affordable & $27(33.8 \%)$ & $28(35.0 \%)$ & $20(25.0 \%)$ & $5(6.3 \%)$ \\
\hline They tear easily & $12(15.0 \%)$ & $14(17.5 \%)$ & $17(21.3 \%)$ & $37(46.3 \%)$ \\
\hline $\begin{array}{l}\text { They have better quality than } \\
\text { imported products }\end{array}$ & $35(43.8 \%)$ & $44(55.0 \%)$ & $0(0.0 \%)$ & $1(1.3 \%)$ \\
\hline $\begin{array}{l}\text { All Aso Òkè produced have values } \\
\text { which reflect in their quality, colour } \\
\text { and name. }\end{array}$ & $43(53.8 \%)$ & $36(45.0 \%)$ & $1(1.3 \%)$ & $0(0.0 \%)$ \\
\hline $\begin{array}{l}\text { The designs on Aso Òkè are valued } \\
\text { for their traditional colours. }\end{array}$ & $37(46.3 \%)$ & $43(53.8 \%)$ & $0(0.0 \%)$ & $0(0.0 \%)$ \\
\hline $\begin{array}{l}\text { The old Aso Òkè types cannot be } \\
\text { out-dated because of their durability } \\
\text { and usefulness. }\end{array}$ & $45(56.3 \%)$ & $33(41.3 \%)$ & $2(2.5 \%)$ & $0(0.0 \%)$ \\
\hline Aso Òkè of Iseyin is costly & $25(31.3 \%)$ & $25(31.1 \%)$ & $21(26.3 \%)$ & $9(11.3 \%)$ \\
\hline $\begin{array}{l}\text { Aso Òkè is valued because they are } \\
\text { culturally important and relevant. }\end{array}$ & $45(56.3 \%)$ & $34(42.5 \%)$ & $1(1.3 \%)$ & $0(0.0 \%)$ \\
\hline $\begin{array}{l}\text { Value is attached to aso-oke because } \\
\text { it can be purchased easily, re-used } \\
\text { and recycled. }\end{array}$ & $17(21.3 \%)$ & $47(58.8 \%)$ & $9(11.3 \%)$ & $7(8.8 \%)$ \\
\hline Aso Òkè is appreciated for events & $46(57.5 \%)$ & $30(37.5 \%)$ & $4(5.0 \%)$ & $0(0.0 \%)$ \\
\hline $\begin{array}{l}\text { A washing machine cannot be } \\
\text { employed for Aso-oke. }\end{array}$ & $24(30.0 \%)$ & $35(43.8 \%)$ & $18(22.5 \%)$ & $3(3.8 \%)$ \\
\hline $\begin{array}{l}\text { Aso-oke is appreciated as Agbada, } \\
\text { Buba, Sokoto, Fila, Iro, Iborun and } \\
\text { Gele. }\end{array}$ & $44(55.0 \%)$ & $36(45.0 \%)$ & $0(0.0 \%)$ & $0(0.0 \%)$ \\
\hline Aso Òkè is no more in vogue. & $12(15.0 \%)$ & $12(15.0 \%)$ & $18(22.5 \%)$ & $38(47.5 \%)$ \\
\hline
\end{tabular}

\section{Users Perception of the Use of Aso-oke}

Almost all the respondents were positively inclined that Aso Òkè was durable and lasted long. Majority (95.0 percent) agreed that Aso Òkè was appreciated for social events. Local fabrics such as Aso Òkè carry social significance among the Yoruba and suitable for events such as chieftaincy and festivals. ${ }^{13}$ These fabrics were prestigious and function as ceremonial cloths.

They strongly agreed that they felt comfortable when wearing them and that they were affordable (33.8 percent). However, most (46.3 percent) strongly disagreed that Aso Òkè could tear easily. Aso Òkè has better quality than imported products as supported by 43.8 percent. Also, 46.3 percent strongly agreed that the designs were highly valued for their traditional colours. Aso Òkè was valued because they are culturally important and relevant (56.3 percent) but 47.5 percent strongly disagreed that was no more in vogue. Users of local

\footnotetext{
${ }^{13}$ T. M. Akinwumi, Ero: A celebration of Eldership in the Indigo Cloths of Owo in Renne E. P \& William B. A (eds.) Yoruba Religious Textiles, (Ibadan, African Book Builders, 2005), 49.
} 
fabrics such as Aso Òkè indicated that it communicated status, prestige, beauty and aesthetics. $^{14}$

\section{Conclusion}

This research has documented weaving activities at Iseyin. It revealed that weaving is sometimes influenced by the availability of capital, low patronage, and cost of maintaining loom, among others. The study has also shown that customers value Aso Òkè because they were culturally important and relevant and they could be purchased easily, reused and recycled. However, a very small percentage of the producers operated on a large scale and a considerable percentage of the consumers consider Aso Òkè to be costly.

More efforts should be made by weavers to preserve the weaving of our local fabrics as a reflection of our cultural heritage. If we don't do this, our local fabric will soon go into extinction. Consumers should not relent in the patronage of local fabrics as their patronage is the source of encouragement to the weavers. Financial support from government to small scale enterprises in Aso Òkè is recommended as this will increase the number of producers operating on a large scale.

Training, improved distribution chain, research and development among others can contribute to the development in the weaving practices of Aso Òkè as it proves to be a source of foreign exchange.

${ }^{14}$ I. J. Diyaolu, "Role of the dresses in Socio-cultural events among the Ijebu-Yoruba, Ogun State, Nigeria. Journal of Home Economics Research.” no. 13 (2010), 35-41. 


\section{Bibliography}

Ajala, O. Aso-oke Yoruba handwoven textiles, The Guardian on Saturday, October $9,2010$.

Asakitipi, A. O. Functions of handwoven textiles among Yoruba Women in Southwestern Nigeria, Nordic Journal of African Studies 16(1) 101-115, 2007

Agbadudu, A. B. and Ogunrin,F. O.. Aso-oke: A Nigerian classic style and fashion fabric. Journal of Fashion Marketing Management.10: 97-113, 2006

Asehinde B. The History of Aso-Oke Textile. Available online at http://digest.bellafricana.com/the-history-of-aso-oke-textile/ (Accessed 30/9/2018) (2017).

Bray, J. The Organization of Traditional Cloth Production in Iseyin, Nigeria. Economy Development Culture Change 17(4), 1968.

Diyaolu, I. J. Technology Assessment of Nigerian Textile Industry. Unpublished PhD Thesis, African Institute for Science Policy and Innovations, Obafemi Awolowo University, Ile-Ife, Nigeria, 2016.

Fadipe, N. A. The Sociology of the Yoruba. Ibadan:Ibadan University Press, 1970.

Idowu, E. B. Olodumare- God in Yoruba belief. Longmans of London, 1962

Ojo, G. J. A. Yoruba Culture. London: University Press, 1966.

Perani, J. "Traditional, Technology and Lurex. Some Comment on Textile History and Design in West Africa" History, design and Craft in West African Stripe Woven Cloth, Washington DC: Smithsonian Institution, 1992.

Perani, J. \& Wolff, N. H. Cloth, dress and art patronage in Africa Oxford: New York, 1999.

Renne, E. P. "Traditional Modernity" and the Economics of Handwoven cloth production in southwestern Nigeria. Economic Development and Cultural Change. 45(4): 773-792, 1997. 